\title{
SUPERCLEAN STEEL PRODUCTION TECHNOLOGY FOR GAS TURBINE COMPRESSOR DISCS AT VILLARES METALS S.A.*
}

\author{
Mário César Mantovani ${ }^{1}$ \\ Paulo Augusto Morais de Oliveira² \\ Maurício Marino Ura ${ }^{3}$ \\ Luciano Wagner de Paula 4 \\ Almir Murari ${ }^{5}$ \\ Robson Leandro Silva ${ }^{6}$ \\ Egberto Antonio Possente ${ }^{7}$ \\ Maurício Trombini ${ }^{8}$ \\ Bruno Pessoa Ramos ${ }^{9}$ \\ Gerson Graciano ${ }^{10}$
}

\begin{abstract}
The steel for gas turbine compressor discs (26NiCrMoV14.5) requires some mechanical properties like strength, impact, toughness, fatigue, and creep resistance in order to be used in such application. To achieve the properties required for the gas turbine compressor discs, the material should have very low contents of sulfur, phosphorus, antimony, tin and arsenic. The level of cleanliness should also be very high and this is possible by achieving low oxygen content keeping the deoxidation elements like silicon, manganese and even the aluminum in very low percentages. The main problem in refining such steel is to adjust a sufficiently low oxygen content to have a good desulfurization and at same time a good cleanliness without using silicon, manganese or aluminum as deoxidizers. Combination of initial selection material, steelmaking process control, forging sequence and heat treatment cycles can provide uniform mechanical properties throughout the gas turbine compressor discs. Villares Metals SA as a big player on special steels with complex process has been developing this kind of material for several years. The objective of this work is to show the process technology evolution involved in the production of this kind of steel under the discussed preconditions.
\end{abstract}

Keywords: Superclean steel; Inclusions; Heat treatment; Forging.

2 Metallurgical Eng., Production Manager, Forging Shop, Villares Metals S.A., Sumaré, SP, Brazil.

3 Metallurgical Eng., Production Manager, Special Melting Shop, Villares Metals S.A., Sumaré, SP, Brazil.

4 Metallurgical Eng., MSc., Senior Product Eng., Product Engineering, Villares Metals S.A., Sumaré, $S P$, Brazil.

5 Civil Eng., Production Manager, Melting Shop, Villares Metals S.A., Sumaré, SP, Brazil.

6 Metallurgical Eng., Senior Process Eng., Melting Shop, Villares Metals S.A., Sumaré, SP, Brazil.

7 Process Technician, Process Specialist, Melting Shop, Villares Metals S.A., Sumaré, SP, Brazil

8 Engineer, Ultrasonic Testing Specialist, Quality, Villares Metals S.A., Sumaré, SP, Brazil.

9 Metallurgical Eng., Production Director, Melting Shop, Villares Metals S.A., Sumaré, SP, Brazil.

10 Mechanical Eng., Production Director, Forging Shop, Villares Metals S.A., Sumaré, SP, Brazil. 


\section{INTRODUCTION}

The adverse effects of impurity elements such as phosphorous $(P)$, antimony $(\mathrm{Sb})$, tin $(\mathrm{Sn})$, arsenic (As), sulfur (S), oxygen (O), and deoxidizers such as aluminum (Al) and silicon ( $\mathrm{Si}$ ) on the mechanical properties of steels have been known for many decades. $\mathrm{P}, \mathrm{Sb}, \mathrm{Sn}$ and As interactively with $\mathrm{Si}$ and $\mathrm{Mn}$ cause temper embrittlement and lead to reduction in the fracture toughness $\left(\mathrm{K}_{1 \mathrm{C}}\right)$ and increase in the ductile-brittle transition temperature (FATT). Presence of sulfide inclusions, and non-metallic inclusions containing $\mathrm{Al}$ and Si can facilitate cavity nucleation at the grain boundaries and in the grains, thus facilitating creep fractures at high temperatures and ductile fractures in the upper shelf region. These changes result in reduced creep ductility at high temperatures and reduced fracture toughness at lower temperatures. Owing to the advancements in steelmaking technology, mainly with respect to secondary refining, have enabled reduction of some these impurities and deoxidizers to levels as low 20 ppm leading to what might be called "clean" steels. Further realization that in view of the low sulfur levels achievable, even $\mathrm{Mn}$ is no longer necessary to "fix" the sulfur and can, therefore, be reduced to levels as low as 0.01 to $0.02 \%$ has resulted in "superclean" steels. [1]

\subsection{Historical Development}

It has been known for many that purity NiCrMoV steels produced in laboratory are immune to temper embrittlement. This was first shown by Balajiva et al. [2, 3] in 1956, and was confirmed by Gould [4] in 1967. McMahon [5] demonstrated that the combination of $\mathrm{Mn}, \mathrm{Si}$, and $\mathrm{P}$ was more detrimental to $21 / 4 \mathrm{Cr}-1 \mathrm{Mo}$ steel than $\mathrm{P}$ alone, and Watanabe [6] showed that the coexistence of $\mathrm{Mn}$ and Si together with the grain boundary segregates, $\mathrm{P}$ and $\mathrm{Sn}$, promoted temper embrittlement in NiCrMoV and CrMo steels. By combining these compositional effects into a J-factor defined as:

$$
\mathrm{J}=(\mathrm{Mn}+\mathrm{Si})(\mathrm{P}+\mathrm{Sn})
$$

Watanabe [6] found that $\mathrm{J} \geq 100 \times 10^{-4}$ was sufficient to make $21 / 4 \mathrm{Cr} 1 \mathrm{Mo}$ steel susceptible to temper embrittlement. NiCrMoV steel is more susceptible and can be embrittled at $\mathrm{J} \geq 10 \times 10^{-4}$. Other such factors have been proposed to include the embrittling effects of As and Sb as well: $[7,8]$

$$
\begin{aligned}
& J^{\star}=(M n+S i)(P+S n+S b) \\
& J^{* *}=(M n+S i)(P+S n+S b+A s)
\end{aligned}
$$

Temper embrittlement is evidenced by changes in the fracture appearance transition temperature (FATT). FATT is the temperature at which Charpy V-notch specimens exhibit $50 \%$ brittle $/ 50 \%$ ductile fracture appearance. The lower the FAAT the more resistant is the material to initiation of brittle fracture. The susceptibility of the steel to temper embrittlement can be determined by measuring the shift in FATT ( $\triangle$ FATT) (or the change in toughness or Charpy $\mathrm{V}$-notch impact energy) for the steel after thermal exposure in the temperature embrittlement range.

After several years of laboratory and experimental work to characterize a temper embrittlement resistant NiCrMoV steel, Electric Power Research Institute (EPRI) in USA developed a composition specification for superclean 3.5NiCrMoV forgings. In fact, in order to carried out the project for development of high purity steels, EPRI in the middle of 80's commissioned the Vereinigte Edelstahlwerke AG - VEW (now Böhler Edelstahl Gmbh), Japan Steel Works (JSW) and Kobe Steel (KS). The aim and actual composition levels supplied according to the specification are shown in Table 1. Because of its exceptional purity and freedom from $\mathrm{Mn}$ and $\mathrm{Si}$, this rotor 
forging was designated as of "superclean" quality, free to the maximum extent possible of $\mathrm{Mn}, \mathrm{Si}, \mathrm{P}, \mathrm{Sn}, \mathrm{As}, \mathrm{Sb}, \mathrm{O}$, and $\mathrm{N}$. Since that forging, a number of trial and production rotor forgings have been made from superclean steel. Various experimental and research projects have sought to characterize the production, metallurgy, and properties of the superclean steel. A complete report of these various investigations through early 1989 can be found in the reports from EPRI. [9]

Table 1 - Aim and actual chemical composition of first super clean prototype rotors. [1]

\begin{tabular}{ccccc}
\hline Element & Aim & VEW & JSW & KS \\
\hline $\mathrm{C}$ & 0.27 & 0.3 & 0.25 & 0.25 \\
$\mathrm{Si}$ & 0.02 & 0.03 & 0.01 & 0.03 \\
$\mathrm{Mn}$ & 0.02 & 0.02 & 0.03 & 0.04 \\
$\mathrm{P}$ & 0.002 & 0.0024 & 0.003 & 0.002 \\
$\mathrm{~S}$ & 0.001 & 0.001 & 0.001 & 0.0012 \\
$\mathrm{Cr}$ & 1.65 & 1.68 & 1.77 & 1.75 \\
$\mathrm{Mo}$ & 0.45 & 0.41 & 0.41 & 0.36 \\
$\mathrm{Ni}$ & 3.5 & 2.44 & 3.66 & 3.68 \\
$\mathrm{Al}$ & $<0.005$ & 0.005 & $<0.005$ & na \\
$\mathrm{As}$ & $<0.002$ & 0.0024 & 0.006 & na \\
$\mathrm{Cu}$ & $\mathrm{na}$ & 0.004 & na & na \\
$\mathrm{N}$ & 0.005 & 0.0032 & na & na \\
$\mathrm{Sn}$ & $<0.002$ & 0.09 & 0.003 & 0.002 \\
$\mathrm{~V}$ & 0.1 & $<0.01$ & na & 0.1 \\
$\mathrm{~W}$ & $\mathrm{na}$ & 0.0027 & na & na \\
$\mathrm{O}$ & 0.0025 & $<0.005$ & 0.0017 & na \\
$\mathrm{Sb}$ & $<0.002$ & 0.7 & na & na \\
$\mathrm{H}(\mathrm{ppm})$ & 0.5 & & & na \\
\hline
\end{tabular}

At Vereinigte Edelstahlwerke - VEW (now Böhler Edelsthal Gmbh) an extensive development program was carried out in order to fulfill the following objectives: (1) to understand better the theoretical background of the process; (2) to develop a tool to improve the reproducibility of the results, and (3) to lower the production process cost by shortening the refining time. According to the Meyer et al. [10], the production of superclean steel for the steelmakers is mainly a problem of deoxidation and, modern ladle refining processes, using a combination of ladle furnace and vacuum degassing, are a powerful tool to achieve steadily increasing requirements for chemical composition and cleanliness of special steels.

After several years of development and consolidation of the superclean steel production at Böhler Edelsthal Gmbh, Dr. Wilfried Meyer, a prominent austrian metallurgist and after his retirement, brought to the Villares Metals SA the entire know-how for superclean steel production. Now Villares Metals SA is a certified company by Siemens for supplying gas turbine compressor discs of superclean steel (26NiCrMoV14.5).

\section{MATERIAL AND METHODS}

\subsection{Steelmaking practice}

After careful scrap selection (to minimize tin, arsenic, and antimony content), melting was performed in an electric arc furnace (EAF). The electric arc furnace has a power supply of 24 MVA and a capacity of 40 t. The ladle furnace (LF) is equipped with 6 MVA power supply, providing heating rates of $3.5^{\circ} \mathrm{C} / \mathrm{min}$. The stiring is done by argon gas introduced through a porous plug in the bottom of the ladle. The vacuum degassing (VD) tank can reach a minimum pressure of 0.5 mbar. 
The melting down and dephosphorization in the EAF take several hours under an oxidizing slag, during which the phosphorous content is drastically reduced. In the same way, $\mathrm{Mn}$ and Si are removed by oxidation in the EAF operation. After EAF tapping and deslagging, lime and flux are added into LF to make a slag of high basicity and low oxygen potential, which removes the sulfur. Vacuum treatment of the desulfurized steel in the LF accompanied by argon bubbling provides a means for deoxidation via the $\mathrm{CO}$ formation (vacuum carbon deoxidation). Temperature and oxygen activity measurements were performed at specific stages of the secondary refining period. Steel and slag samples were taken for chemical analysis and nonmetallic inclusion characterization. The non-metallic inclusions were characterized by using an electron probe microanalysis (EPMA), model JEOL 8253, equipped with an energy dispersive spectroscopy (EDS) analyzer.

\subsection{Ingot casting and Forging}

The steel was bottom poured under a protective atmosphere into a $26 \mathrm{t}$ ingot mould by uphill casting. A conventional hot top was situated on top of the mould with a top and bottom discharges of $18 \%$ and $5 \%$ of the volume, respectively. It was used a 5000 ton hydraulic press for open die forging. The disc positions inside the ingot are described in Figure 1. The forging sequence comprises the steps of ingot heating, stretching (forged blank), reheating and up setting.

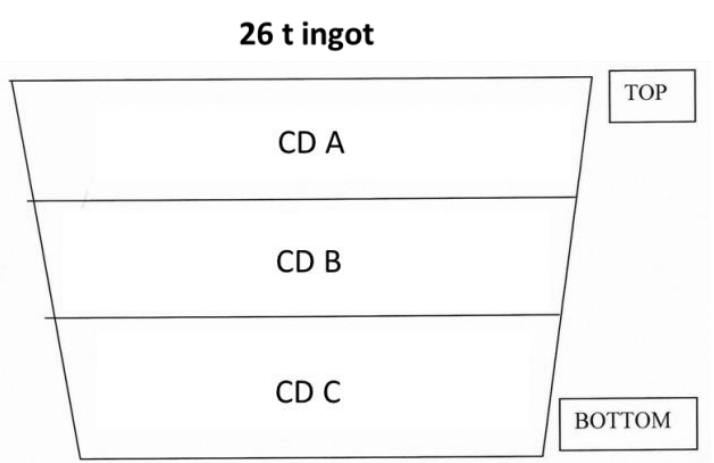

Figure 1 - Schematic description of disc positions inside the $26 \mathrm{t}$ ingot.

\subsection{Heat treatment}

The quality heat treatment of compressor disc comprises the steps of normalizing, quenching and tempering. Temperature, holding time and heating and cooling rates are important parameters to achieve uniform properties. After rough machining of the heat treated forging (normalizing), a preliminary ultrasonic inspection is carried out, and if there is no indication together with low sound absorption, this is an indicative of fine grain size and, therefore, good quality. After quenching and tempering, the disc with bore is machined (finish machining) to the shape required for final ultrasonic testing.

\subsection{Ultrasonic testing}

Extensive testing was carried out using a USN 60 ultrasonic tester according to the test instruction provided by the costumer. It was used three types of probes, and a frequency up to $4 \mathrm{MHz}$. 


\section{RESULTS AND DISCUSSION}

\subsection{Melting and refining}

Table 2 shows the chemical composition and oxygen activities at several stages of the primary and secondary refining during the production of typical superclean steel (26NiCrMoV14.5). At the ending of the primary refining in EAF, the $\mathrm{Si}, \mathrm{Mn}$ e $\mathrm{P}$ contents are already according to aimed specification. Sulfur is removed together with strict control of $\mathrm{Al}$ and $\mathrm{O}$ contents during secondary refining (ladle and vacuum degassing treatments). Vacuum treatment of the desulfurized steel in the tank degassing together with argon bubbling provides a means for deoxidation via carbon monoxide evolution. This leaves fewer oxide particles dispersed in the steel as would occur if deoxidation were done with Si or Al. Heating, slag adjusting, and subsequent vacuum treatment under argon stirring takes several hours. In spite of only $0.003 \%$ $\mathrm{Al}$, even this low aluminum content plays an important role in the deoxidation of such steels $[10,11]$. If only the first-order interaction coefficients for the activity coefficient are considered [12], deoxidation reaction by $\mathrm{Al}$ is given by eq. (1), with its equilibrium and activities by eqs. (2) through (6). Inserting eqs. (5) and (6) to eq. (4) gives eq. (7).

$$
\begin{aligned}
& \mathrm{Al}_{2} \mathrm{O}_{3}(\mathrm{~s})=2 \underline{\mathrm{Al}}+3 \underline{\mathrm{O}} \\
& \log \mathrm{K}=11 \cdot 62-45,300 / \mathrm{T} \\
& K=\frac{a_{A l}^{2} \cdot a_{O}^{3}}{a_{A l 2 O 3}}
\end{aligned}
$$

The logarithm of the equilibrium equation (3) gives:

$$
\begin{aligned}
& \log K=2 \log f_{A l}+2 \log [\% A l]+3 \log f_{o}+3 \log [\% O]-\log a_{A l 2 O 3} \\
& \log f_{A l}=e_{A l}^{A l}[\% A l]+e_{A l}^{o}[\% O] \\
& \log f_{o}=e_{o}^{A l}[\% A l]+e_{o}^{o}[\% O] \\
& +2 \log [\% A l]+3 \log [\% O]-\log a_{A l 2 O 3} \log K=\left(2 e_{A l}^{A l}+3 e_{o}^{A l}\right)[\% A l]+\left(2 e_{A l}^{o}+3 e_{o}^{o}\right)[\% O]
\end{aligned}
$$

where, $a_{0}$ and $a_{A l}$ are the activities of elements aluminum and oxygen in molten steel relative to a dilute solution of one mass percent standard state, and $\mathrm{aAl}_{\mathrm{A} 2 \mathrm{O} 3}$ is the activity of alumina relative to a pure solid standard state. The oxygen contents in equilibrium with alumina in the slag can be calculated by eq. 7 . However, the slag is considered to be in the lime saturated region of the $\mathrm{CaO}-\mathrm{Al}_{2} \mathrm{O}_{3}-\mathrm{MgO}$ slag system, which means that there is a sufficient $\mathrm{Ca}$ content in the steel that the deoxidation product is not pure alumina, but calcium aluminate, which shifts the oxygen activity to low levels. In equilibrium with a slag inclusion where alumina activity is less than 1 , equation (3) may be used to obtain ao. Calcium aluminate slags highly reduced are used in order to achieve low oxygen activity in the bath and, therefore, the compositional control of the slag used during the ladle refining is of outstanding importance. In fact, the main problem in refining such steel is to adjust a sufficient low oxygen content, on the one hand to have a good precondition for desulfurization, and on the other hand to get a steel with high cleanliness without using $\mathrm{Si}, \mathrm{Mn}$, or Al. Molten steel treatment is considered finished when the following evidences are reached: (a) $\mathrm{CO}$ evolution has almost ceased during vacuum treatment and; (2) oxygen activity measurement indicates a value that is close to equilibrium calculation. 
Table 2 - Chemical composition, temperature and oxygen activity measurements at several stages of the secondary refining period of superclean steel production.

\begin{tabular}{|c|c|c|c|c|c|}
\hline$\%$ & $\begin{array}{c}\text { After EAF } \\
\text { (primary refining) }\end{array}$ & $\begin{array}{l}\text { After LF treatment } \\
\text { (sample-S1) }\end{array}$ & $\begin{array}{c}\text { After VD } \\
\text { treatment } \\
\text { (sample-S2) }\end{array}$ & $\begin{array}{l}\text { After Ar bubbling } \\
\text { (sample S3) }\end{array}$ & Casting \\
\hline $\mathrm{C}$ & 0.03 & 0.15 & 0.27 & na & 0.28 \\
\hline $\mathrm{Si}$ & 0.01 & 0.01 & 0.022 & na & 0.02 \\
\hline $\mathrm{Mn}$ & 0.02 & 0.017 & 0.036 & na & 0.036 \\
\hline$P$ & 0.002 & 0.002 & 0.0028 & na & 0.0028 \\
\hline$S$ & 0.012 & 0.0047 & 0.0017 & na & 0.0017 \\
\hline Co & 0.01 & 0.01 & 0.01 & na & 0.01 \\
\hline $\mathrm{Cr}$ & 0.05 & 0.04 & 1.66 & na & 1.67 \\
\hline Mo & 0.33 & 0.42 & 0.43 & na & 0.43 \\
\hline $\mathrm{Ni}$ & 0.03 & 3.64 & 3.59 & na & 3.59 \\
\hline V & 0.01 & 0.01 & 0.123 & na & 0.125 \\
\hline W & 0.01 & 0.01 & 0.01 & na & 0.01 \\
\hline $\mathrm{Cu}$ & 0.02 & 0.02 & 0.02 & na & 0.02 \\
\hline $\mathrm{Ti}$ & 0.005 & 0.005 & 0.005 & na & 0.005 \\
\hline $\mathrm{Nb}$ & 0.01 & 0.01 & 0.01 & na & 0.01 \\
\hline $\mathrm{Al}$ & na & na & 0.0025 & na & 0.0028 \\
\hline Sn & 0.0029 & 0.0023 & 0.0029 & na & 0.0031 \\
\hline $\mathrm{N}$ & na & na & 0.0065 & na & 0.009 \\
\hline $\mathrm{H}$ & na & na & na & na & 0.0008 \\
\hline$a_{\circ}$ & na & 0.0038 & 0.0018 & 0.0016 & na \\
\hline${ }^{\circ} \mathrm{C}$ & na & 1706 & 1593 & 1569 & na \\
\hline $\mathrm{O}_{\mathrm{t}}$ & na & na & na & na & 0.0027 \\
\hline
\end{tabular}

na $=$ not analyzed

The types of the non-metallic inclusions found at different stages of the production are described in Table 3. Spinel particles are only found at the beginning of the LF treatment. From the first VD treatment the non-metallic inclusions present a spherical shape (liquid oxide solution at steelmaking temperature) and its composition resembles more the top slag composition, despite the high $\mathrm{SiO}_{2}$ content found in most of the non-metallic inclusions. In the final product the non-metallic inclusions are also spherical in shape, but are richer in $\mathrm{MgO}$, which culminates in the precipitation of the spinel crystal inside the oxide solution during cooling [14].

Table 3 - Types of non-metallic inclusions found at different stages of the production.

\begin{tabular}{|c|c|c|c|c|}
\hline & \multicolumn{3}{|c|}{ Process steps } & \multirow[b]{2}{*}{$\begin{array}{c}\text { Final product } \\
\text { (S4) }\end{array}$} \\
\hline Types & $\begin{array}{c}\text { After LF } \\
\text { treatment (S1) }\end{array}$ & $\begin{array}{c}\text { After VD } \\
\text { treatment (S2) }\end{array}$ & $\begin{array}{c}\text { After argon } \\
\text { bubbling (S3) }\end{array}$ & \\
\hline Oxide solution & & & $x$ & $x$ \\
\hline Oxide solution with minor amount of S & & $\mathrm{X}$ & & $\mathrm{X}$ \\
\hline Oxide solution having high $\mathrm{SiO}_{2}$ content & & & $\mathrm{x}$ & \\
\hline Spinel $\left(\mathrm{MgAl}_{2} \mathrm{O}_{4}\right)$ & $\mathrm{X}$ & & & \\
\hline Spinel surrounded by an oxide solution & & & & $\mathrm{X}$ \\
\hline
\end{tabular}

\subsection{Heat treatment and metallurgical properties of superclean steel}

With careful steelmaking practice and appropriate heat treatment, the production of superclean steels with uniform properties for gas turbine compressor discs is absolutely achievable. Uniformity of properties is achieved in part by subsequent heat treatment. Since it is difficult to impart uniform forging strain from surface to center of relatively thick sections, differences in the recrystallized austenite grain size are probably brought about by differences in the amount of hot work developed in the forging process. Heat treatment can rectify this nonuniformity. Typically this is accomplished by cycling the steel through the austenite-bainite transformation. An additional benefit is that short range compositional differences are also smoothed by diffusion during the elevated temperature portions of the heat treatment. Thus, both 
transformation cycling and some combination of time and temperature during austenitizing are important to uniformity. $[1,11]$

Hardenability is dependent primarily on the composition of the steel, and in conventional forgings some portion of hardenability comes from the Mn content in excess of that required to tie up the $S$ in the steel. Figure 2 shows the continuous cooling transformation diagram of superclean steel (26NiCrMoV14.5). In fact, the superclean steel (26NiCrMoV14.5) presents adequate hardenability to develop tempered martensite and bainite microstructure.

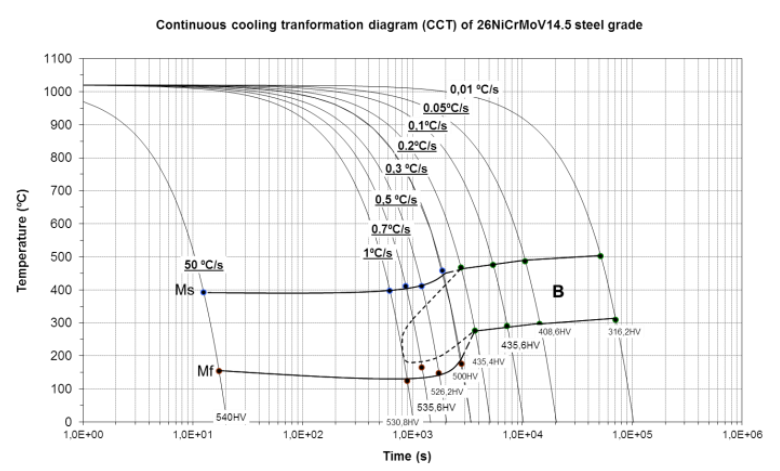

Figure 2 - CCT diagram of superclean 26NiCrMoV14.5 steel.

\subsection{Ultrasonic testing}

There was no recordable indication above $0.7 \mathrm{~mm}$ equivalent flaw diameter in all compressor disks produced from ingot presented in Figure 1 (CD B). The sound attenuation measurements were always lower than $2.0 \mathrm{~dB} / \mathrm{m}$, which is an indicative of fine grain size.

\subsection{Mechanical properties measurements}

Test rings T1 and T2 (dimensions of $35 \mathrm{~mm}$ length and $55 \mathrm{~mm}$ thickness) were taken from the discs according to schematic view shown in Figure 3. Considering test ring $\mathrm{T} 1$, at $12^{\circ \circ}$ and $6^{\circ \circ}$ were taken 18 specimens (180 $\mathrm{mm}$ length) for impact and FATT tests. At the same positions 4 specimens (135 $\mathrm{mm}$ length) were taken for tensile tests. On the other hand, for test ring T2, at $9^{\circ \circ}$ and $3^{\circ \circ}$ were taken 18 specimens for impact and FATT tests (ASTM A370). At the same positions 3 specimens were taken for tensile tests.

In all cases the FATT (50/50) test results presented values higher than $50 \mathrm{~J}$ as shown in Figure 4 (CD B), for instance. In fact, temper embrittlement susceptibility in superclean steel can be eliminated by reducing impurities ( $\mathrm{Mn}, \mathrm{Si}, \mathrm{P}, \mathrm{Sn} \mathrm{As}, \mathrm{Sb})$ to very low contents. This compositional control can be achieved by a combination of steelmaking process control and initial material selection. 


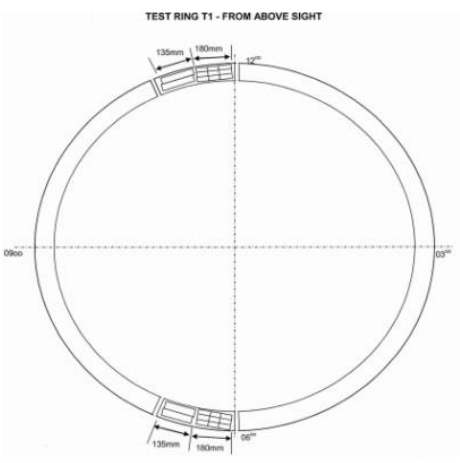

(b)

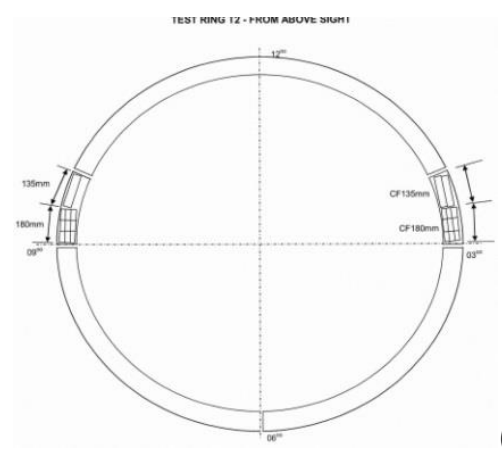

(c)

Figure 3 - Positions and dimensions of the test rings.

Tables 4 and $\mathbf{5}$ show the specification and the results of tensile and impact tests at room and high temperature, respectively, for compressor disc B (CD B). Very similar results were also found in samples taken from compressor discs $A$ and $C$, which were produced from the same ingot as described in Figure 1. Uniformity of properties is induced in large measure through proper choice of heat treatment in this kind of forging that is reasonably uniform with respect to composition.
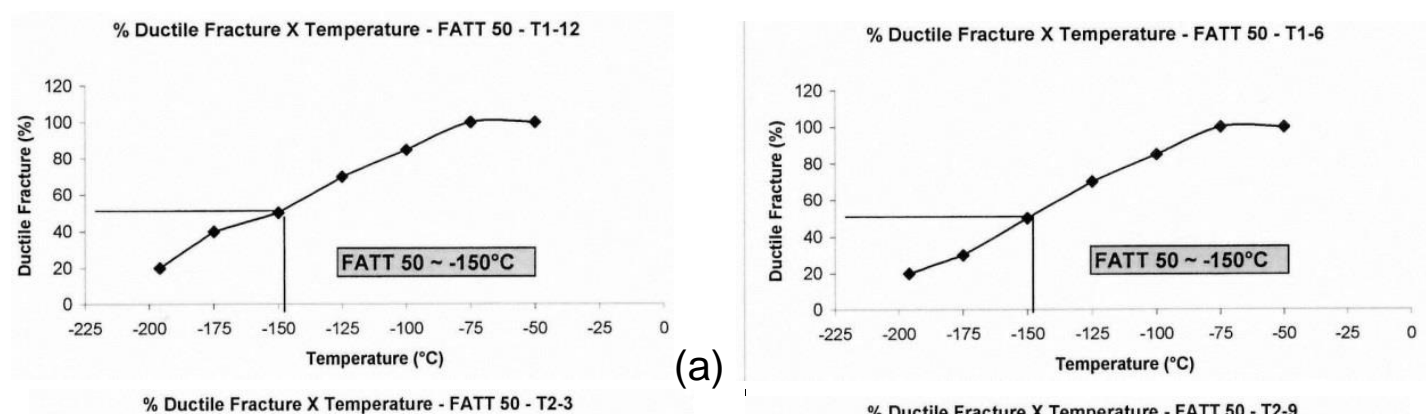

(b)
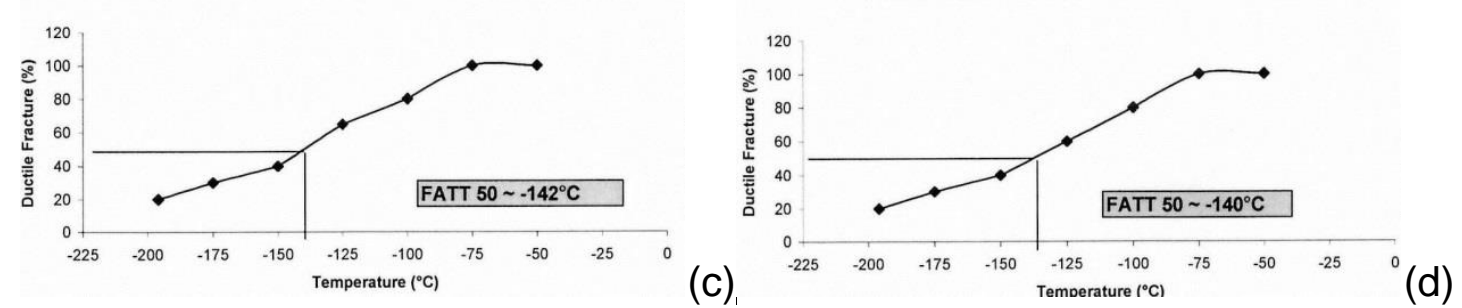

Figure 4 - FATT 50 test results. (a) test ring $\mathrm{T} 1$ at $12^{\circ \circ}$; (b) test ring $\mathrm{T} 1$ at $6^{\circ \circ}$; (c) test ring T2 at $3^{\circ \circ}$ and; (d) test ring T2 at $9^{\circ \circ}$.

Table 4 - Tensile and impact tests at room temperature for compressor disc B (CD B).

\begin{tabular}{|c|c|c|c|c|c|c|c|c|c|}
\hline \multicolumn{6}{|c|}{ Tensile test at room temperature } & \multicolumn{4}{|c|}{ Impact $(\mathrm{J})$ at room temperature } \\
\hline $\begin{array}{l}\text { Position } \\
\text { in the } \\
\text { drawing }\end{array}$ & Direction & UTS/MPa & $\begin{array}{c}0.2 \% \\
\text { (YS/Mpa) }\end{array}$ & $\begin{array}{l}\text { ROA } \\
(\%)\end{array}$ & $\mathrm{El}(\%)$ & Direction & ${ }^{\circ} \mathrm{C}$ & Notch & $\begin{array}{c}\text { Three } \\
\text { specimens }\end{array}$ \\
\hline--- & $\begin{array}{c}\text { Transvers } \\
\text { e tang. }\end{array}$ & $810-960$ & $700-800$ & $>=50$ & $>=15$ & $\begin{array}{c}\text { Transvers } \\
\mathrm{e}\end{array}$ & room & $\begin{array}{c}\text { Charpy } \\
\text { "v" }\end{array}$ & $\begin{array}{l}\text { Individual } \\
\text { \& media }\end{array}$ \\
\hline \multicolumn{6}{|c|}{ Tensile test at $22^{\circ} \mathrm{C}$ results } & \multicolumn{4}{|c|}{$\operatorname{Impact}(\mathrm{J})$ at $22^{\circ} \mathrm{C}$ results } \\
\hline $\begin{array}{l}\text { Position } \\
\text { in the } \\
\text { drawing }\end{array}$ & Direction & UTS/MPa & $\begin{array}{c}0.2 \% \\
\text { (YS/Mpa) }\end{array}$ & $\begin{array}{l}\mathrm{ROA} \\
(\%)\end{array}$ & $\mathrm{El}(\%)$ & $\begin{array}{c}\text { Sample } \\
61\end{array}$ & 62 & 63 & Average \\
\hline$T 1-12^{\circ \circ}$ & --- & 897 & 792 & 74.4 & 15.2 & 188.3 & 176.7 & 185.9 & 183.6 \\
\hline & & & & & & \multicolumn{4}{|c|}{$\begin{array}{l}\text { Ductile fracture surface is equal } 100 \% \text { for } \\
\text { each sample above }\end{array}$} \\
\hline $\begin{array}{l}\text { Position } \\
\text { in the } \\
\text { drawing }\end{array}$ & Direction & UTS/MPa & $\begin{array}{c}0.2 \% \\
\text { (YS/Mpa) }\end{array}$ & $\begin{array}{l}\text { ROA } \\
(\%)\end{array}$ & El (\%) & $\begin{array}{c}\text { Sample } \\
79\end{array}$ & 80 & 81 & Average \\
\hline $\mathrm{T} 1-6^{\circ 0}$ & --- & 892 & 786 & 73.4 & 15.4 & 188.1 & 184.4 & 200.4 & 191.0 \\
\hline & & & & & & \multicolumn{4}{|c|}{$\begin{array}{l}\text { Ductile fracture surface is equal } 100 \% \text { for } \\
\text { each sample above }\end{array}$} \\
\hline
\end{tabular}


Table 5 - Hot tensile test for compressor disc B (CD B).

\begin{tabular}{|c|c|c|c|c|c|c|}
\hline \multicolumn{7}{|c|}{ Hot tensile test } \\
\hline $\begin{array}{l}\text { Position in } \\
\text { the drawing }\end{array}$ & Direction & ${ }^{\circ} \mathrm{C}$ & UTS/MPa & $0.2 \%(\mathrm{YS} / \mathrm{MPa})$ & ROA (\%) & El (\%) \\
\hline --- & $\begin{array}{c}\text { Transverse } \\
\text { tang. }\end{array}$ & 450 & $>=610$ & $>=515$ & $>=60$ & $>=17$ \\
\hline \multicolumn{7}{|c|}{ Results } \\
\hline $\begin{array}{l}\text { Position in } \\
\text { the drawing }\end{array}$ & & TUS/MF & & $0.2 \%(\mathrm{YS} / \mathrm{MPa})$ & ROA (\%) & El (\%) \\
\hline $\mathrm{T} 1-12^{\circ \circ}$ & & 682 & & 598 & 84.0 & 17.2 \\
\hline$T 1-6^{\circ 0}$ & & 674 & & 597 & 84.2 & 17.7 \\
\hline
\end{tabular}

In summary, the production of superclean steel for gas turbine compressor discs is based on a strict control of melt composition and its cleanliness by using careful scrap selection, deep dephosphorization in the EAF and an intensive secondary refining, which comprises ladle furnace and vacuum degassing practices for desulfurization and deoxidation. After forging and heat treatment, the ultrasonic testing indicated exceptional freedom from detectable defects. The resistance to temper embrittlement was excellent, as expected from the low Mn and Si contents. The required yield and tensile strengths as well as impact properties were beyond expectations.

\section{CONCLUSION}

Superclean steel production technology for gas turbine compressor discs comprises a steelmaking practice, casting, forging and heat treatment that ensure the following requirements: a) low $\mathrm{Mn}, \mathrm{Si}, \mathrm{Al}, \mathrm{P}, \mathrm{S}, \mathrm{Sn}, \mathrm{Sb}, \mathrm{N}, \mathrm{H}$ and $\mathrm{O}$ contents; b) high cleanliness without using $\mathrm{Si}, \mathrm{Mn}$, or Al as deoxidizers; c) high resistance to temper embrittlement together low FATT as a result of its low Mn and Si contents and; d) exceptional yield and tensile strengths as well as impact properties in the three compressor discs produced from the same ingot, indicating uniform properties provided by forging and heat treatment procedures.

\section{In memoriam}

This work is dedicated to the memory of our brilliant colleague Mr. Wilfried Meyer who has brought to the Villares Metals S.A. the entire know-how on superclean steel technology production and whose passion for metallurgy is our eternal inspiration.

\section{REFERENCES}

11 McNaughton, MC; Richman, RH and Jaffee, RI: "Superclean" 3.5NiCrMoV Turbine Rotor Steel: Status Report - Pat I: Steelmaking Practice, Heat Treatment and Metallurgical Properties. Journal of Materials Engineering, 1991, v. 13, p. 9-18.

2 Balajiva, K; Cook, RM and Worn, D.K: Nature, 1956, v. 178, p. 433.

3 Stevens and Balajiva, K: Journal of Iron and Steel Institute. 1959, v. 193, p. 14.

4 Gould, GC: Symposium on Temper Embrittlement in Steel, ASTM STP 407, p. 59-73. ASTM, Philadelphia, 1968.

5 McMahon, CJ; Takayama, S; Ogura, T; Fu, S-C; Murza, JC; Graham, WR; Yen, AC and DiDio, R: Elimination of Impurity-Induced Embrittlement in Steel, NP-1501, Part 1, Electric Power Research Institute, Palo Alto, California, USA, 1980.

6 Watanabe, J and Murakami, Y: Prevention of Temper Embrittlement of CrMo Steel Vessels by the Use of Low-Silicon Forged Shells, p. 216-223, Americam Petroleum Institute, Washington, DC, USA, 1981. 
7 Kohno, H; Miyakawa, M; Kinoshita, S and Suzuki, A: Effect and Chemical Composition on Properties of High Purity 3.5NiCrMoV Steel, ASM-EPRI, Intl. Conf. Advances in Materials Technology for Fossil Power Plants, Chicago, USA, September 1-3, 1987.

8 Bruscato, RM: Welding Journal Research Supplement, 1970, v. 35, p. 148s.

9 Jaffee, RI; Richman, RH and McNaughton, WP: Superclean Steel Development: An Interim Report, RP1403-32, Electric Power Research Institute - EPRI, Palo Alto, California, USA, 1989.

10 Meyer, W; Kucharz, A and Hochörtler, G: "Production of Superclean Steels Deoxidation Mechanism During Ladle Refining," Residual and Unspecified Elements in Steel, ASTM STP 1042, A.S. Melilli and E.G. Nisbett, Eds., American Society for Testing and Materials, 1989, p. 38-47.

11 Jaffee, Rl; Machner, P; Meyer, W and Steiner, JE: Ironmaking and Steelmaking, 1986, v. 13, No. 6, p. 322-326.

12 Todoroki, H.; Mizuno, K.: I\&S, 2003, v. 30, No. 3, p.60-67.

13 Itho, H.; Hino, M., and Ban-Ya, S.: Metallurgical and Materials Transactions B, 1997, v. 28B, p. 953-956.

14 Kim, J.W.; Kim, S. K.; Kim, D.S.; Lee, Y.D. and Yang, P.K.: ISIJ International. 1996, 36, Supplement, S140-S143. 